\title{
Variation in hierarchical guild structure between two bird assemblages of a wetland in the Mexican Pacific
}

\author{
Mateo D. M. Ruiz Bruce Taylor ${ }^{1 *}$, José Luis Rangel Salazar ${ }^{1}$, Paula L. Enríquez ${ }^{1}$, \\ Jorge L. León-Cortés ${ }^{1} \&$ Carlos García-Estrada ${ }^{2}$ \\ 1. Departamento Conservación de la Biodiversidad, El Colegio de la Frontera Sur, Carretera Panamericana \\ y Periférico Sur s/n. Barrio de María Auxiliadora, 29290 San Cristóbal de Las Casas, Chiapas, México; \\ truiz@ecosur.edu.mx, jlrangel@ecosur.mx, penrique@ecosur.mx, jleon@ecosur.mx \\ 2. Instituto de Ecología, Universidad del Mar, km 1.5, Carretera a Sola de Vega, 71980 San Pedro Mixtepec, Oaxaca, \\ México; cgarcia@zicatela.umar.mx \\ * Correspondence.
}

Received 15-IX-2016. Corrected 28-VI-2017. Accepted 26-VII-2017.

\begin{abstract}
Neotropical wetlands comprise contrasting habitats with highly diverse avifauna, including herbivores, insectivores and carnivores, of both terrestrial and aquatic species. Therefore, comparisons between wetland bird assemblages based only on species identity may disregard turnover within ecological groups, and eclipse important variations between habitat types. We studied bird assemblages from mangrove and estuary habitat types from a coastal lagoon system in Oaxaca, Mexico. For this, we used 640 point counts to obtain data on bird species using those habitats between October 2009 and May 2012. We ascertained guild structure by classifying 139 species in a scalar hierarchy of two-levels: 17 key-resource guilds nested within seven trophic guilds. To evaluate variation in guild structure between habitat types, we contrasted richness and diversity across trophic guilds and tested for variation in abundance within key-resource guilds. We exposed a tendency of greater diversity within terrestrial guilds in mangrove and within aquatic guilds at the estuary. However, these differences were compensatory and neither richness nor diversity varied between habitat types in comparisons across the sets of trophic guilds. Parallel analyses at two hierarchical levels supported the theoretical prediction of greater change at lower levels. Herpetofauna, wood invertebrates, aquatic invertebrates and seeds emerged as dietary components that may explain the distribution of abundance in key-resource guilds. Although the guilds from mangrove and estuary produced comparable sets of richness and diversity values, the actual identity of guilds with high values varied between habitats. On the other hand, species abundance comparisons within guilds pinpointed specific associations with habitat types and this method represents a suitable strategy for identifying habitat preferences in complex wetland bird assemblages. Rev. Biol. Trop. 65 (4): 1540-1553. Epub 2017 December 01.
\end{abstract}

Key words: Aves, key-resource guild, trophic guild, hierarchy theory, mangrove, estuary, Oaxaca.

Bird assemblages are complex systems containing high numbers of different and interacting elements. This makes inference about their attributes analytically challenging (Simon, 1962) and the quantitative appraisal of changes between these assemblages can be hard to formulate and understand. In tropical bird assemblages, system complexity can be intensified by high levels of local richness (e.g., Herzog, Kessler, \& Cahill, 2002). Moreover, the ecological disparity between bird species in tropical wetlands is unusually marked as these assemblages contain both aquatic and terrestrial species.

Hierarchy theory provides a model for simplifying complex systems, whereby entities at higher hierarchical levels are used to interpret or generalize the behavior of entities at lower levels (Salthe, 2012). Delineating ecological groups of species is one method of recognizing entities at a hierarchical level above species but below assemblage. Although 
a guild can be broadly defined as any group of species that are similar in an ecologically relevant way (Wilson, 1999), the original concept was specifically developed in the context of competition between bird species (Root, 1967) and that research agenda is on-going (e.g., Rodríguez, Jansson, \& Andrén, 2007). Alternatively, guild members are perceived to converge on abundant resources (Jaksić, 1981; Hubbell, 2005) and this view enables comparisons between assemblages and the analysis of how resources or habitat variables shape assemblage structure (Mac Nally, 1994; Blaum, Mosner, Schwager, \& Jeltsch, 2011; GonzálezSalazar, Martínez-Meyer, \& López-Santiago, 2014). Because they are taxonomically circumscribed, bird guilds are a class of assemblage guild (Jaksić, 1981), which is synonymous with ensemble (Fauth et al., 1996).

Identifying ecological groups within guilds produces a guild hierarchy (Wilson, 1999; Pianka, 2000). In a scalar hierarchy, the constituent entities at higher hierarchical levels apply to a greater range of components than those at lower levels (Salthe, 2002; 2006). Because trophic guilds are sets of species populations that share broadly similar trophic resources (Burns, 1989), they occupy a higher level in a scalar hierarchy than a set of species sharing one principle resource. We refer to the latter group as a key-resource guild. Although hierarchy theory has led to promising developments in community ecology (Kolasa, 1989; Kolasa \& Pickett, 1989; Allen \& Hoekstra, 1990), to our knowledge, it has not been explicitly applied to guild structure.

The inherent nature of change in hierarchical structure makes it necessary to distinguish between trivial and significant variation in guild structure (Kolasa \& Pickett, 1989). Intuitively, we anticipate greater differences to be perceived as the resolution we compare at becomes finer (i.e. at lower hierarchical levels) and this expectation is compatible with hierarchy theory, which conceives a continuum of increasing frequencies as one descends in level (Allen \& Starr, 1982). The derived concept of minimum interactive structure contrasts significant change at the highest level with configurational change at lower levels (Kolasa \& Pickett, 1989). Therefore, tests carried out at higher levels yield more robust conclusions.

In this study we focus on bird assemblages from two contrasting habitat types using a scalar hierarchy as a conceptual framework and bird guilds as operational sub-units (Blondel, 2003). We used data obtained over 32 months to derive measures of species abundance, guild richness, and guild diversity in both mangrove and estuary. These habitat types are distinguished in terms of vegetation and hydrology and we define microhabitats as fine-scale attributes that are used by birds to obtain resources (Fuller, 2012).

As species richness across multiple guilds has been termed guild structure (Pianka, 1980), we refer to species richness and diversity across a set of guilds as diversity structure. In this context, we hypothesized that if specific resources and microhabitats are available to different degrees in mangrove and estuary, then a consistent between-habitat trend across the set of guilds would be unlikely. Therefore, diversity structure should not vary even though guild composition may. We also considered how habitat association within guilds relates to the availability of resources and microhabitats.

Our initial objective was to establish and implement criteria for species membership in a hierarchy of key-resource guilds nested within trophic guilds. Secondly, we predicted a lack of variation in the diversity structure of trophic guilds between mangrove and estuary. Thirdly, we identified the resources and microhabitats that potentially influenced abundance within key-resource guilds (González-Salazar et al., 2014). Finally, we evaluated the theoretical prediction that variation between habitat types in diversity structure and species abundance would be greater in key-resource guilds than in trophic guilds (Kolasa \& Pickett, 1989).

\section{MATERIALS AND METHODS}

Study site: The Ventanilla-Tonameca coastal lagoon system is in Oaxaca State, 
South West Mexico (between parallels 1549'26" N - 096³4'53" W). The Tonameca River is the main freshwater input to the system, which comprises $\sim 700$ ha of wetland sheltered from the Pacific Ocean by a barrier beach. The climate is warm and sub-humid, with average temperatures between $26{ }^{\circ} \mathrm{C}$ and $28{ }^{\circ} \mathrm{C}$. Annual precipitation is between 800 $1000 \mathrm{~mm}, 97 \%$ of which falls between May and October (Binford, 1989; Trejo, 2004).

The mangrove habitat type at the Ventanilla lagoon constituted approximately 150 ha of red (Rhizophora mangle) and white (Laguncularia racemosa) mangrove trees, 10 - $20 \mathrm{~m}$ in height, with average stem density of 12458 trees/ha, (C. Tovilla, unpublished). The hydroperiod was precipitation-regulated (Ruiz, Rangel-Salazar, \& Cortés, 2013) and tropical dry forest covered surrounding hills (Fig. 1; Digital Appendix 1).

The estuary habitat type at the Tonameca lagoon presented a mosaic of successional stages, including monocotyledons, herbaceous species, and scattered trees ( $\sim 20$ trees/ha with height $<6 \mathrm{~m}$; M. Ruiz, unpublished). Palm, grassland and swamp forest fringed the landward edge (Fig. 1; Digital Appendix 1). A seasonal tidal inlet was open at the Tonameca lagoon between June and November.

Bird sampling: We based sampling design on intensive point counts (Ralph et al., 1992) and used repeat counts to increase the precision of species composition estimates (Ralph, Droege, \& Sauer, 1995). Monthly, 10 minute, $25 \mathrm{~m}$ radius point counts were carried out at 20 count sites (Fig. 1; Digital Appendix 1) between October 2009 and May 2012, producing a total of 32 counts per site $(\mathrm{N}=$ 640). Points within lagoons were separated by $>100 \mathrm{~m}$ (mean distance to nearest neighbor $=143 \mathrm{~m}, \mathrm{SD}=50 \mathrm{~m}$ ) and the spatial extent of sampling was therefore similar to other intensive studies of birds in mangroves (e.g., Noske,

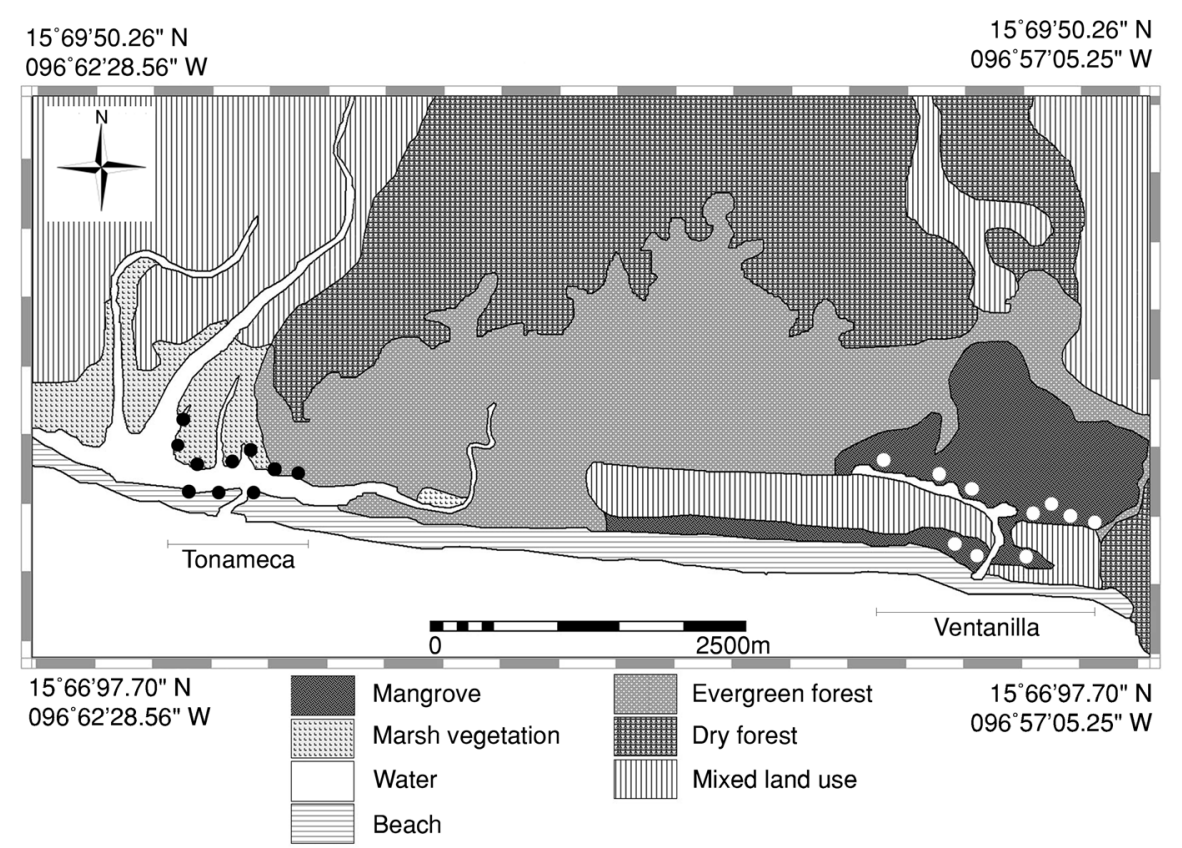

Fig. 1. Twenty sites used for point counts of the bird assemblage in the Ventanilla-Tonameca lagoon system on the Pacific coast of Oaxaca State, Southern Mexico. Counts were made in mangrove (Ventanilla) or at an un-wooded estuary (Tonameca), between October 2009 and May 2012. Mixed land use includes regrowth, palm plantations, agricultural land, and gardens. Information on specific count sites is in Digital Appendix 1. (Created using ILWIS, 2005). 
1996; Lefebvre \& Poulin, 1997; Sodhi, Choo, Lee, Quek, \& Kara, 1997), where distances between sample sites may be unavoidably short (Johnson \& Sherry, 2001; Gómez-Montes \& Bayly, 2010). Birds observed arriving from the area of a previous sample were not re-recorded (Ralph et al., 1995).

Point locations were determined by accessibility and reached on foot or by paddle boat, depending on water levels (Bojorges-Baños, 2011). An average of $3.88 \mathrm{~km}(\mathrm{SD}=0.38)$ separated the Ventanilla points from those in Tonameca. Three or four points were visited in random sequence and counts were made within the first two hours of daylight (dawn ranged from 05:30 to 06:30 standard time). To minimize disturbance, all field work was carried out by MRBT, unaccompanied. MRBT had three years of experience in bird identification at the study site prior to sampling (Ruiz \& Bojorges, 2014).

We obtained quantitative descriptions of microhabitat use to evaluate the extent to which birds used the lagoon to obtain resources, and in which microhabitats. We used a subset of point counts $(\mathrm{N}=288)$ with increased duration (20 minutes) and radius $(50 \mathrm{~m})$ to obtain single point observations (Morrison, 1984). We recorded the substrate birds occupied using coarse descriptions to accommodate heterogeneity across habitat types (Noon, 1981). Categories were: airspace, deep water surface, shallow water, vegetated shore, sandy shore, wet sediments, sand, dead branches, non-woody aquatic vegetation, and terrestrial vegetation (herbaceous plants, shrubs and all trees). We did not use foraging height because Tonameca was largely tree-less and species vary foraging height according to vegetation structure (Stiles, 1980). When possible we registered whether individuals were foraging or not. Where birds were not foraging (e.g. loafing, nesting, bathing) or activity was undetermined, the substrate they occupied was not included as microhabitat used for resource consumption (Wiens, 1989).
Species diet: We conducted journal database searches to consult specialized literature describing species' diets, as well as using species field guides (e.g., Paulson, 2005; Howell \& Dunn, 2007). Information came from stomach contents, feces, pellets, regurgitations, stable isotopes, prey items at nests and foraging observations. We gave priority to research from the same habitat or region as the study site (e.g. Eguiarte \& Martínez del Rio, 1985; Herrera, Hobson, Martínez, \& Méndez, 2006).

The resources described were assigned to categories, eight of which were taken from Appendix 3 of Rappole, Morton, Lovejoy, and Ruos (1983): vegetative parts of terrestrial plants, fruit, nectar, terrestrial seeds, terrestrial invertebrates (including arboreal and aerial), soil and leaf-litter invertebrates, plankton and aquatic plant matter, and aquatic vertebrates. We subdivided two other categories used by Rappole et al. (1983): 1) Within terrestrial vertebrates we separated herpetofauna from birds and mammals, and 2) within aquatic invertebrates we separated water column/surface invertebrates from infauna. We also added crabs and carrion (Hiraldo, Delibes, \& Donazar, 1991; Miranda \& Collazo, 1997), giving a total of 14 categories.

We qualitatively classified the importance of resource categories as minor, significant, or major (Rappole et al., 1983). To determine values for these classes, we obtained the number of significant and major resource categories in the diets of 91 relevant species reported in Rappole et al. (1983). Using the modal and mean number of categories per species, we determined values of $0.05,0.45$ and 0.9 for minor, significant and major resource classes, respectively. We attributed class values to dietary categories and rescaled so that proportions summed to unity for each species.

Guild membership: We changed the grain of diet observations in order to identify levels in a feeding-defined scalar hierarchy (Allen \& Hoekstra, 1990). Food utilization 
was the primary criteria at both first-order (trophic guilds) and second-order (key-resource guilds) levels: Trophic guilds contained species that share an aggregated resource category and key-resource guild species shared a specific resource category.

To form aggregated resource categories, we lumped specific resource categories into trophic levels as plant matter (1), invertebrates (2) or vertebrates (3), and then sub-divided these as terrestrial ('t') or aquatic ('a'; Fig. 2). Abbreviations of trophic guilds consist of the relevant letter and number (e.g. aquatic herbivores $=$ 'al'). We did not assign carrion to a trophic level, although detritus is sometimes treated as a basal species (Williams \& Martinez, 2004). The usual criterion for trophic guild membership was a minimum proportion of 0.5 consumption of an aggregated category. However, we used $\geq 0.33$ consumption of aquatic plant matter for 'a1' and we also identified a group of aquatic secondary consumers with $<0.5$ consumption of aquatic trophic level 2, and $>0.64$ of combined aquatic levels 2 and 3 . Ten species were excluded from trophic guilds (Digital Appendix 2).

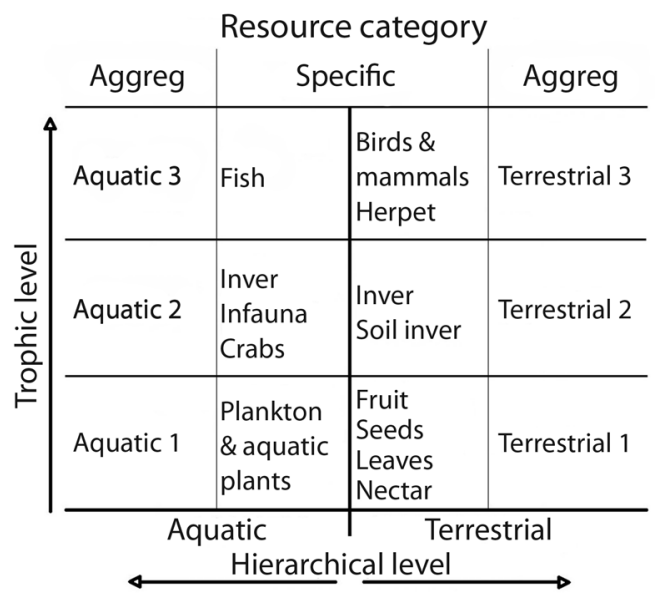

Fig. 2. Hierarchical structure in food resource categories of the Ventanilla-Tonameca bird assemblage in wetlands of Oaxaca, Mexico. Specific food resources are nested within aggregate categories that comprise trophic levels of aquatic or terrestrial resources. Arrows indicate increase in level. Abbreviations: aggreg $=$ aggregated, inver $=$ invertebrates, and herpet $=$ herpetofauna .
To form key-resource guilds, we first identified sub-groups of species consuming a common core resource. Core resources were the specific category constituting the greatest portion of a trophic guild's collective diet: fruit, terrestrial invertebrates, birds and mammals, aquatic plants and phytoplankton, aquatic invertebrates, and aquatic vertebrates. In general, we used an inclusion criterion of $\geq 0.25$ core resource consumption and stipulated that consumption be greater than or equal to that of any other category. Two exceptions were: 1) sub-groups of species from the same trophic guild with $\geq 0.25$ consumption of a shared alternative resource; and 2) sub-groups based on combined resource categories. Alternative resource categories were seeds, herpetofauna and crabs. Combined resource categories were terrestrial invertebrates and fruit (Herrera et al., 2006), and terrestrial invertebrates and nectar (Remsen, Stiles, \& Scott, 1986; Lefebvre \& Poulin, 1997).

A secondary criterion specified that species exploit a common microhabitat for food utilization, as characterized by foraging substrate. We used single point observations to divide some sub-groups by the specific substrates where they foraged: airspace used by insectivores, shallow water used by insectivores, and deep water used by piscivores (Digital Appendix 2). In three cases we assumed that resources were obtained by foraging activity in microhabitats we could not directly observe: deep water (fish), covered sediments (infauna), and wood (invertebrates). Eight species were excluded from key-resource guilds (Digital Appendix 2).

Comparisons between habitat types: We combined data from count sites within lagoons because intensive point count sampling reduces independence between observations (Ralph et al., 1992). We also pooled observations across the annual cycle to obtain general measures of species abundances (Lefebvre \& Poulin, 1997). Species abundance estimates within lagoons were therefore the sum of 32 repeated counts at each of 10 sites $(\mathrm{N}=320)$. 
Tests comparing diversity structure between mangrove and estuary were carried out with trophic guilds and key-resource guilds using Hill's diversity numbers (1973). For each guild in each lagoon, we obtained the number of species, the reciprocal of Simpson's concentration index $\left(1 / \sum p_{i}^{2}\right)$, and the exponential function of Shannon's diversity index (base= e; PRIMER-E Ltd, 2007). We used generalized linear models to compare mean values of diversity numbers from Ventanilla and Tonameca $(\alpha=0.05$ ), using the quasipoisson link function for nonnegative data with positive skewness and overdispersion (Silva \& Tenreyro, 2006; Crawley, 2007; R Core Team, 2013).

We compared species abundance between lagoons within key-resource guilds, trophic guilds and groups of aquatic and terrestrial birds, using a criterion of $>0.5$ consumption of combined aquatic or terrestrial resources to assign species to the latter groups. We assessed variable distributions using Shapiro-Wilk tests, with P-values adjusted for multiple comparisons (Holm, 1979; Legendre \& Legendre, 1998), and used a variance ratio test if variables from both lagoons complied $(\alpha=0.05$ in both cases; R Core Team, 2013).

We compared the guild or group abundance vector for Ventanilla with that of Tonameca using t-tests when assumptions were justifiable, or Wilcoxon rank sum tests otherwise. We used the equivalent paired tests in guilds and groups containing herons and ibis that exhibit coarse-scale habitat selection (Bildstein, Post, Johnston, \& Frederick, 1990; Strong, Bancroft, \& Jewell, 1997). These were species that were regularly observed flying between Ventanilla and Tonameca. We used one-tailed tests if guild richness and abundance presented consistent differences between habitat types, otherwise we used two-tailed tests ( $\alpha=0.05$; R Core Team, 2013). P-values were adjusted due to concurrent measurements on multiple guilds (Holm, 1979; Mac Nally, 1994; Lefebvre \& Poulin, 1997). In guilds with insufficient species for testing (less than five) we interpreted the absence of any individuals in a lagoon as evidence of lower abundance.

\section{RESULTS}

Bird sampling: We recorded 149 bird species during point counts, 1976 individuals of 77 species in Ventanilla, and 5885 individuals of 118 species in Tonameca. We obtained 6315 single point observations of 117 species (70 species with $\geq 10$ observations), of which 1995 observations of 69 species involved foraging (26 species with $\geq 10$ observations).

Species diet: Digital Appendix 2 includes a bibliography of 105 scientific articles containing information on the diet of bird species recorded during sampling. Complementary information from personal observations or publications on congeners was incorporated for seven species and for another three these were the only references available.

Guild membership: We classified 139 species in seven trophic guilds: terrestrial herbivores (' $\mathrm{t} 1$ ', including granivores and frugivores), terrestrial insectivores ('t2'), terrestrial carnivores (' $\mathrm{t} 3$ '), aquatic herbivores ('a1'), aquatic insectivores ('a2'), aquatic generalists ('a2.5') and piscivores ('a3'). All trophic guilds were represented by at least two species in both habitat types. We excluded Fulica americana from analyses due to strong inter-annual abundance fluctuations. We classified 131 species in 17 key-resource guilds, 13 of which were present in both lagoons. Resource categories and substrates of keyresource guilds ' $a$ ' to ' $\mathrm{q}$ ' are in table 1 and table 2 , and details on guild membership are in Digital Appendix 2.

Comparisons between habitat types: In general, diversity was higher in terrestrial guilds at Ventanilla, and richness and diversity were higher in aquatic guilds at Tonameca (Fig. 3 ). Across guilds, diversity structure did not vary between lagoons in comparisons of trophic guilds with $\mathrm{N}_{0}$ (coefficient $=0.38, \mathrm{P}=0.44$, Ventanilla $=10.6($ mean $)$, Tonameca $=15.4), \mathrm{N}_{1}$ (coefficient $=0.09, \mathrm{P}=0.82$, Ventanilla $=5.9$, Tonameca $=6.5$ ), or $\mathrm{N}_{2}$ (coefficient $=-0.07$, 
TABLE 1

Abundance of terrestrial birds at two hierarchical guild levels in a coastal lagoon system in Oaxaca, Mexico. Comparisons are between observations from mangrove in Ventanilla and estuary at Tonameca

\begin{tabular}{lccccc}
\multicolumn{1}{c}{ Guild/group ${ }^{1}$} & $\mathrm{Ven}^{2}$ & $\mathrm{Ton}^{2}$ & $\mathrm{H}_{1}{ }^{3}$ & $\mathrm{~V}^{4}$ & $\mathrm{P}^{5}$ \\
Terrestrial species $(\mathrm{N}=85)$ & 1458 & 1378 & $\mathrm{~L} 1>\mathrm{L} 2$ & 4041 & $0.52(0.09)$ \\
Terrestrial herbivores: $\mathrm{t} 1 \mathrm{~N}=21)$ & 403 & 192 & $\mathrm{~L} 1>\mathrm{L} 2$ & 262.5 & $0.58(0.14)$ \\
a: fruit $(\mathrm{N}=14)$ & 400 & 95 & $\mathrm{~L} 1>\mathrm{L} 2$ & 165 & $0.02^{*}(<0.01)$ \\
b: seeds $(\mathrm{N}=7)$ & 3 & 97 & $\mathrm{~L} 1<\mathrm{L} 2$ & 2.5 & $0.03^{*}(<0.01)$ \\
Terrestrial insectivores: $\mathrm{t} 2(\mathrm{~N}=51)$ & 985 & 848 & $\mathrm{~L} 1 \neq \mathrm{L} 2$ & 1379 & $1.00(0.59)$ \\
c: fruit/invertebrates $(\mathrm{N}=9)$ & 117 & 22 & $\mathrm{~L} 1>\mathrm{L} 2$ & 64 & $0.20(0.02)$ \\
d: nectar/invertebrates $(\mathrm{N}=3)$ & 121 & 12 & $\mathrm{~L} 1 \neq \mathrm{L} 2$ & $\mathrm{n} / \mathrm{a}$ & $\mathrm{n} / \mathrm{a}$ \\
e: leaf and stem invertebrates $(\mathrm{N}=25)$ & 458 & 325 & $\mathrm{~L} 1 \neq \mathrm{L} 2$ & 329 & $1.00(0.75)$ \\
f: invertebrates in wood $(\mathrm{N}=3)$ & 78 & 0 & $\mathrm{~L} 1>\mathrm{L} 2$ & $\mathrm{n} / \mathrm{a}$ & $\mathrm{n} / \mathrm{a}^{\dagger}$ \\
g: invertebrates in the airspace $(\mathrm{N}=8)$ & 59 & 185 & $\mathrm{~L} 1<\mathrm{L} 2$ & 12 & $0.20(0.02)$ \\
Carnivores: $\mathrm{t} 3(\mathrm{~N}=9)$ & 51 & 5 & $\mathrm{~L} 1>\mathrm{L} 2$ & 63.5 & $0.20(0.02)$ \\
h: birds and mammals $(\mathrm{N}=6)$ & 14 & 5 & $\mathrm{~L} 1>\mathrm{L} 2$ & 22.5 & $0.75(0.25)$ \\
i: herpetofauna $(\mathrm{N}=3)$ & 37 & 0 & $\mathrm{~L} 1>\mathrm{L} 2$ & & $\mathrm{n} / \mathrm{a}^{\dagger}$ \\
\hline
\end{tabular}

1. Trophic guilds are in italics and are followed by their abbreviation, key-resource guilds are denoted with letters and are followed by the food resource that defines them. $\mathrm{N}=$ number of species.

2. Abundance measures are total counts obtained over 32 months (October 2009 and May 2012). Ven = Ventanilla lagoon and Ton $=$ Tonameca lagoon.

3. Directional hypotheses are posited when tendencies in species richness and abundance are consistent. L1 = Ventanilla lagoon and L2 = Tonameca lagoon.

4. V is from the Wilcoxon rank sum test.

5. P-values are adjusted for multiple tests $(k=20$; Holm, 1979), unadjusted values are in parenthesis, $*=$ significant difference with $\alpha=0.05, \dagger=$ difference is not statistically inferred, but derived from the absence of any individuals of a given guild in one or other lagoon.
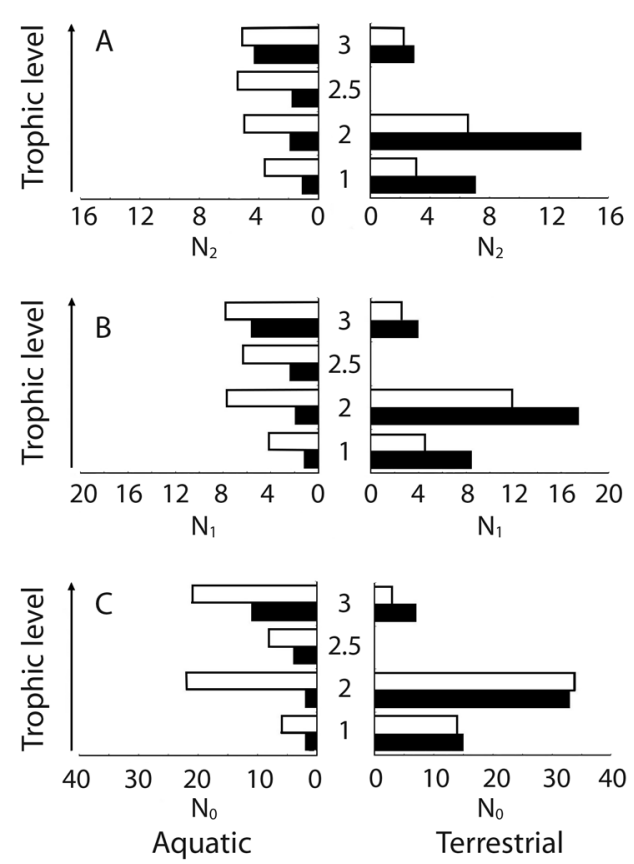

$\mathrm{P}=0.86$, Ventanilla $=4.8$, Tonameca $=4.4$ ). Neither was there variation between lagoons in comparisons of key-resource guilds $\left(\mathrm{N}_{0}\right.$ coefficient $=0.36, \mathrm{P}=0.28$, Ventanilla $=4.1$, Tonameca $=5.9 ; \mathrm{N}_{1}$ coefficient $=0.17, \mathrm{P}=0.49$, Ventanilla $=2.5$, Tonameca $=3.0 ; \mathrm{N}_{2}$ coefficient $=0.10, \mathrm{P}=0.71$, Ventanilla $=2.1$, Tonameca $=2.3$ ).

With one exception, normal distributions proved unlikely for abundance vectors

Fig. 3. Diversity structure of a bird assemblage from the Ventanilla-Tonameca coastal lagoon system in Southern Mexico. Black bars represent trophic guilds in mangrove (Ventanilla) and white bars in un-wooded estuary (Tonameca). Diversity numbers $\left(\mathrm{N}_{2}, \mathrm{~N}_{1}\right.$ and $\left.\mathrm{N}_{0}\right)$ are shown for aquatic and terrestrial trophic guilds at trophic levels 1 (herbivores), 2 (insectivores) and 3 (carnivores or piscivores). Graph ' $\mathrm{A}$ '= reciprocal of Simpson's dominance index, 'B' = exponent of Shannon's diversity index, and ' $\mathrm{C}$ ' $=$ species richness. 
TABLE 2

Abundance of aquatic birds at two hierarchical guild levels in a coastal lagoon system in Oaxaca, Mexico. Comparisons are between observations from mangrove in Ventanilla and estuary at Tonameca

\begin{tabular}{lccccc}
\multicolumn{1}{c}{ Guild/group ${ }^{1}$} & $\mathrm{Ven}^{2}$ & $\mathrm{Ton}^{2}$ & $\mathrm{H}_{1}{ }^{3}$ & $\mathrm{~V}^{4}$ & $\mathrm{P}^{5}$ \\
Aquatic species $(\mathrm{N}=62)$ & 518 & 4412 & $\mathrm{~L} 1<\mathrm{L} 2$ & 275 & $<0.01^{*}(<0.01)$ \\
Aquatic herbivores: a1 $(\mathrm{N}=6)$ & 24 & 153 & $\mathrm{~L} 1<\mathrm{L} 2$ & 4.5 & $0.20(0.02)$ \\
j: aquatic plants $(\mathrm{N}=6)$ & 24 & 153 & $\mathrm{~L} 1<\mathrm{L} 2$ & 4.5 & $0.20(4.5)$ \\
Aquatic insectivores: a2 $(\mathrm{N}=22)$ & 5 & 2095 & $\mathrm{~L} 1<\mathrm{L} 2$ & 7 & $<0.01^{*}(<0.01)$ \\
k: invertebrates on shoreline $(\mathrm{N}=11)$ & 2 & 1076 & $\mathrm{~L} 1<\mathrm{L} 2$ & 2 & $<0.01^{*}(<0.01)$ \\
1: swimming invertebrates $(\mathrm{N}=6)$ & 0 & 838 & $\mathrm{~L} 1<\mathrm{L} 2$ & 0 & $0.02^{*}(<0.01)$ \\
m: infauna $(\mathrm{N}=3)$ & 0 & 19 & $\mathrm{~L} 1<\mathrm{L} 2$ & $\mathrm{n} / \mathrm{a}$ & $\mathrm{n} / \mathrm{a}^{\dagger}$ \\
Aquatic generalists: a2.5 $(\mathrm{N}=8)$ & 29 & 145 & $\mathrm{~L} 1<\mathrm{L} 2$ & 0 & $0.07(<0.01)$ \\
n: fish and swimming invertebrates $(\mathrm{N}=5)$ & 22 & 91 & $\mathrm{~L} 1<\mathrm{L} 2$ & 0 & $0.34(0.03)$ \\
o: crabs $(\mathrm{N}=2)$ & 4 & 38 & $\mathrm{~L} 1 \neq \mathrm{L} 2$ & $\mathrm{n} / \mathrm{a}$ & $\mathrm{n} / \mathrm{a}$ \\
Piscivores: a3 $(\mathrm{N}=22)$ & 463 & 1076 & $\mathrm{~L} 1<\mathrm{L} 2$ & 75 & $0.72(0.10)$ \\
p: fish in shallow water $(\mathrm{N}=9)$ & 272 & 570 & $\mathrm{~L} 1<\mathrm{L} 2$ & 15 & $0.85(0.21)$ \\
q: fish in deep water $(\mathrm{N}=11)$ & 191 & 413 & $\mathrm{~L} 1 \neq \mathrm{L} 2$ & 36.5 & $0.52(0.10)$ \\
\hline
\end{tabular}

1. Trophic guilds are in italics and are followed by their abbreviation, key-resource guilds are denoted with letters and are followed by the food resource that defines them. $\mathrm{N}=$ number of species.

2. Abundance measures are total counts obtained over 32 months (October 2009 and May 2012). Ven = Ventanilla lagoon and Ton $=$ Tonameca lagoon.

3. Directional hypotheses are posited when tendencies in species richness and abundance are consistent. L1 = Ventanilla lagoon and L2 = Tonameca lagoon.

4. V is from the Wilcoxon rank sum test except for Wilcoxon signed rank tests with 'Aquatic species', 'a2.5', 'a3', 'n' and 'p'.

5. P-values are adjusted for multiple tests $(k=20$; Holm, 1979), unadjusted values are in parenthesis, $*=$ significant difference with $\alpha=0.05, \dagger=$ difference is not statistically inferred, but derived from the absence of any individuals of a given guild in one or other lagoon.

for Ventanilla, Tonameca or both (greater W statistics 0.34-0.67, P-value < 0.001-0.03). In the only guild with non-significant $\mathrm{W}$ statistics for both lagoons, variance differed between samples $\left(\mathrm{F}_{5}=8.68, \mathrm{P}=0.03\right)$. We therefore used non-parametric tests in all cases. Species abundances were substantially higher at Tonameca than Ventanilla for aquatic species and in one, nested trophic guild ('a2'; Table 2). Variation in trophic guilds was contingent on variation in key-resource guilds, but not vice versa. There were 12 key-resource guilds with at least five species and the ratio of significant to nonsignificant tests was 4:8. Abundance was markedly higher at Ventanilla for frugivores (guild ' $a$ ') and higher at Tonameca for granivores ('b'), shore-line aquatic insectivores (' $k$ '), and wading aquatic insectivores ('l'; Table 1 and Table 2). Five key-resource guilds had insufficient species for testing, of which consumers of wood invertebrates and herpetofauna were confined to Ventanilla and consumers of infauna were confined to Tonameca (guilds ' $f$ ', ' $i$ ' and 'm', respectively).

\section{DISCUSSION}

Our use of guilds sought to interpret variation in complex bird assemblages by using dietary information on the species we recorded at Ventanilla-Tonameca, Oaxaca. The two-level hierarchy allowed tests and detailed comparisons to be carried out at first and second-order levels, respectively. Complementary distribution in group-specific richness and diversity led to comparable diversity structure across trophic guilds of mangrove and estuary. A higher frequency of change in key-resource guilds enabled us to identify abundance variation 
that reflected microhabitat and resource availability (González-Salazar et al., 2014).

Our data permitted a direct comparison of general patterns between two discrete bird habitats at a local scale. Repeated counts over three years produced abundance measures that encompassed the influence of temporal dynamics in factors such as precipitation (Jiménez, 2004), between-habitat movements (Rioja-Paradela, Carrillo-Reyes, \& Espinoza-Medinilla, 2014), and lagoon hydrology (Flores-Verdugo, Day, Mee, \& Briseño-Dueñas, 1988). Guild structure may provide a basis for future insight into how temporal dynamics affect fluctuations in migratory bird abundance (M. Ruiz, unpublished).

Trophic resource utilization was the primary criteria for assigning species to guilds. Assigning qualitative categories to dietary resources allowed us to collate a wide range of data and establish a system that integrated terrestrial and aquatic resources. Our approach was similar to that used in a world-wide study, which also incorporated species of diverse ecologies (Kissling, Sekercioglu, \& Jetz, 2011). Where, how or when foraging takes place can be important when classifying bird species in guilds (González-Salazar et al., 2014) and we included foraging microhabitat if it segregated consumers by filtering access to a resource.

The change of grain between aggregated and specific resource categories established a basis for delineating between hierarchical levels (Allen \& Hoekstra, 1990). The resulting structure of the bird assemblage formed a nested, scalar hierarchy that can be represented as [assemblage[trophic guild[key-resource guild[species]]]] (Salthe, 2002). Alternatively, guild delineation takes the approach of a specification hierarchy, sequentially adding information that refines previous criteria (Salthe, 2006). For example, adding foraging maneuvers to membership criteria (Holmes \& Recher, 1986; Adamík, Korňan, \& Vojtek, 2003) applies a further informational constraint on a group of species which share a resource. A specification hierarchy corresponds to a niche hierarchy dendrogram in which different branches correspond to different constraining factors (Sugihara, Bersier, Southwood, Pimm, \& May, 2003). A scalar hierarchy matches a dendrogram that represents an assemblage where only one factor is at work.

Considerable discussion surrounds the definition and application of guilds and related concepts (Jaksić, 1981; Simberloff \& Dayan, 1991; Blondel, 2003; Korňan \& Kropil, 2014). A central reason for concern has been subjectivity in the choice of traits used to classify species (Wilson, 1999), and using directly measured habitat variables has developed in response (Holmes \& Recher, 1986; Adamík et al., 2003). Diet is also advocated as a relatively objective criterion, because it reflects the birds' own selection of resources (Korňan \& Kropil, 2014). Direct measurements of diet have provided much insight into mangrove bird assemblages (Lefebvre \& Poulin, 1997).

Multivariate analyses can reduce bias stemming from subjectivity, although there are some limitations. Stability in multivariate classification is not assured (Cormack, 1971) and this attribute of guild membership is desirable when additional dietary observations or species are incorporated. More importantly, cluster methods of guild assignation are robust when the ratio of species to descriptors is low (Jaksić \& Medel, 1990), for example $<2$ (Holmes, Bonney, \& Pacala, 1979; Holmes \& Recher, 1986) or even fractional (Jaksić \& Medel, 1990; Korňan \& Adamík, 2007). However, this ratio may be high in species-rich assemblages for which ecological information is limited (10.6 for trophic guilds in this study). In these circumstances, alternative methods of classifying species allow researchers to evaluate patterns of resource use among co-occurring species. If more information becomes available, then applying multivariate analyses could provide an interesting opportunity for comparisons between methods (Wiens, 1989; Blaum et al., 2011).

In concordance with our hypothesis, diversity structure did not vary between mangrove and estuary at the first-order hierarchical level (or at the second-order level). Rather 
than similarity across all guilds, this result signals that between-habitat differences in richness and diversity switched direction from guild to guild. Previous research at the study site that did not consider guilds revealed lower richness and diversity in the mangrove (M. Ruiz, unpublished; Ruiz \& Bojorges, 2014). If differences in richness and diversity were consistent between guilds, then diversity structure would have displayed the same pattern. However, diversity distribution varies between guilds (Kissling et al., 2011) and we found diversity peaks in terrestrial trophic guilds of the mangrove, despite its lower assemblagelevel diversity. We interpret this turnover in guild composition as complementarity between habitat types, whereby mangrove and estuary contributed guilds to different degrees (Williams et al., 1996).

In species abundance comparisons, the relationship between levels was consistent with hierarchy theory because between-habitat changes in abundance were always expressed in descending tiers (Allen \& Starr, 1982). A decreasing frequency of change at ascending levels is a key prediction which has been successfully tested using a generalist-specialist spectrum (Waltho \& Kolasa, 1993). Processes taking place at lower hierarchical levels can identify mechanistic or causal explanations for phenomena at higher levels (Pickett, Kolasa, \& Jones, 2007; Salthe, 2012). The effects of habitat selection by individual birds are transmitted up to form patterns of habitat association in populations. By the same token, the sum of interspecific tendencies in habitat selection led to patterns of habitat association in keyresource guilds.

Differences in guild abundance between habitat types provide information about which resources and microhabitats birds use (González-Salazar et al., 2014). Herpetofauna was the core resource of three species in the mangrove and none at the estuary, indicating the importance of arboreal reptiles such as Anolis ssp. in mangroves. Similarly, species predating wood invertebrates were only present in the mangrove. On the other hand, higher abundance in mangrove frugivores is surprising, as fruit were relatively scarce across the lagoon system. However, most frugivorous birds also consume invertebrates and the observed pattern may reflect forest frugivores foraging for invertebrates in the structurally similar mangrove canopy. In Tonameca, the high abundance in shore-line and wading insectivores was probably associated with tidal sediments containing Oligochaeta, Polychaeta, Bivalvia and Crustacea (Stoner \& Acevedo, 1990; Levin et al., 2001). Granivore abundance was likely linked to marsh vegetation of early successional stages in estuarine environments (Gill, 2012), whereas halophytic seed-bearing ground flora is shaded out in mangroves (Snedaker \& Lahmann, 1988).

The guild hierarchy we have presented is perhaps more realistic than an oversimplified, one-level system (Wilson, 1999; Pianka, 2000; Korňan \& Adamík, 2007). Between-habitat similarity in diversity structure contrasted with previous, assemblage-level comparisons, which indicated higher bird diversity at the estuary. Importantly, guild-specific patterns highlighted a higher diversity of terrestrial birds in mangroves. Furthermore, mangroves supported higher abundances of key-resource guilds exploiting tree trunk and branch microhabitats. The abundance of aquatic species and guilds was higher at the estuary. Emergent patterns were consistent with the theoretical prediction of an increased frequency of change at lower hierarchical levels. In order to form hierarchical guild classification criteria, future research should focus on varying the grain of observations of a single phenomenon.

\section{ACKNOWLEDGMENTS}

The Consejo Nacional de Ciencia y Tecnología funded MRBT during fieldwork and manuscript preparation (grant holder 222996). We thank S.C. de C.V. Servicios Ecoturísticos La Ventanilla and the Aragón Arvea family for the loan of boats. We are thankful for helpful assistance with figures and language by L. Ruiz and we are very grateful 
for input from M. A. Martínez Morales and three anonymous referees.

\section{RESUMEN}

Variación en la estructura jerárquica de gremios entre dos ensambles de aves en un humedal del Pacífico de México. Los humedales neotropicales comprenden hábitats contrastantes con avifaunas altamente diversas que incluyen especies terrestres y acuáticas de herbívoros, insectívoros y carnívoros. Por lo cual, las comparaciones entre los ensambles avifaunísticos de los humedales basados únicamente en la identidad de especies podrían ignorar el recambio entre grupos ecológicos, y ocultar variaciones importantes entre tipos de hábitat. Nosotros estudiamos ensambles avifaunísticos de tipos de hábitat de manglar y estuario en un sistema lagunar de la costa de Oaxaca, México. Entre octubre 2009 y mayo 2012, utilizamos 640 puntos de conteo para determinar la estructura de gremios mediante la clasificación de 139 especies en una jerarquía escalar de dos niveles: 17 gremios de recursos claves anidados en siete gremios tróficos. Para evaluar la variación en la estructura jerárquica entre tipos de hábitat, contrastamos la riqueza y diversidad a través de gremios tróficos y probamos para variación en la abundancia dentro de gremios de recursos claves. Registramos una tendencia de mayor diversidad en gremios terrestres del manglar y en gremios acuáticos del estuario. Sin embargo, ésta variación fue compensatoria, ya que ni la riqueza específica ni la diversidad variaron entre los tipos de hábitat a través de los conjuntos de gremios tróficos. Un análisis paralelo de dos niveles jerárquicos soportó la predicción de un mayor recambio en niveles inferiores. La herpetofauna, los invertebrados en madera, los invertebrados acuáticos, y las semillas se presentaron como componentes alimenticios que podrían explicar la distribución de abundancia en los gremios de recursos claves. Aunque los gremios del manglar y estuario produjeron conjuntos comparables de valores de riqueza y diversidad, la identidad exacta de los gremios con valores altos variaba entre hábitats. Por otro lado, las comparaciones de abundancia dentro los gremios determinaron asociaciones específicas con tipos de hábitat y este método representa una estrategia apta para identificar las preferencias de hábitat en ensambles complejos de aves en humedales.

Palabras clave: Aves, gremio de recursos claves, gremio trófico, teoría de jerarquías, manglar, estuario, Oaxaca.

\section{REFERENCES}

Adamík, P., Korňan, M., \&, Vojtek, J. (2003). The effect of habitat structure on guild patterns and the foraging strategies of insectivorous birds in forests. BiologiaBratislava, 58, 275-285.
Allen, T. F. H., \& Hoekstra, T. W. (1990). The confusion between scale-defined levels and conventional levels of organization in ecology. Journal of Vegetation Science, 1, 5-12.

Allen, T. F. H., \& Starr, T. B. (1982). Hierarchy: Perspectives for ecological complexity. Chicago, Illinois: University of Chicago Press.

Bildstein, K. L., Post, W., Johnston, J., \& Frederick, P. (1990). Freshwater wetlands, rainfall, and the breeding ecology of White Ibises in coastal South Carolina. Wilson Bulletin, 102, 84-98.

Binford, L. C. (1989). A distributional survey of the birds of the Mexican State of Oaxaca. Washington DC: American Ornithologists' Union.

Blaum, N., Mosner, E., Schwager, M., \& Jeltsch, F. (2011). How functional is functional? Ecological groupings in terrestrial animal ecology: Towards an animal functional type approach. Biodiversity Conservation, 20, 2333-2345.

Blondel, J. (2003). Guilds or functional groups: Does it matter? Oikos, 100, 223-231.

Bojorges-Baños, J. C. (2011). Richness and diversity of bird species associated with mangrove in three lagoon systems in the coastal region of Oaxaca, Mexico. Revista Mexicana de Biodiversidad, 82, 1-18.

Burns, T. P. (1989). Lindeman's contradiction and the trophic structure of ecosystems. Ecology, 70, 1355-1362.

Cormack, R. M. (1971). A review of classification. Journal of the Royal Statistical Society. Series A (General), 134, 321-367.

Crawley, M. J. (2007). The R book. Chichester, West Sussex: John Wiley \& Sons Ltd.

Eguiarte, L. E., \& Martínez del Rio, C. (1985). Feeding habits of the Citreoline Trogon in a tropical dry forest during the dry season. Auk, 102, 872-874.

Fauth, J. E., Bernardo, J., Camara, M., Resetarits, Jr., W. J., Van Buskirk, J., \& McCollum, S. A. (1996). Simplifying the jargon of community ecology: a conceptual approach. American Naturalist, 147, 282-286.

Flores-Verdugo, F. J., Day, Jr., J. W., Mee, L., \& BriseñoDueñas, R. (1988). Phytoplankton production and seasonal biomass variation of seagrass, Ruppia maritima L., in a tropical mexican lagoon with an ephemeral inlet. Estuaries, 11, 51-56.

Fuller, R. J. (2012). The bird and its habitat: an overview of concepts. In R. J. Fuller (Ed.), Birds and habitat: relationships in changing landscapes (pp. 3-36). New York, NY: Cambridge University Press.

Gill, J. A. (2012). Processes influencing bird use of estuarine mudflats and saltmarshes in western Europe. 
In R. J. Fuller (Ed.), Birds and habitat: relationships in changing landscapes (pp. 307-333). New York, NY: Cambridge University Press.

Gómez-Montes, C., \& Bayly, N. J. (2010). Habitat use, abundance, and persistence of Neotropical migrant birds in a habitat matrix in northeast Belize. Journal of Field Ornithology, 81, 237-251.

González-Salazar, C., Martínez-Meyer, E., \& López-Santiago, G. (2014). A hierarchical classification of trophic guilds for North American birds and mammals. Revista Mexicana de Biodiversidad, 85, 931-941.

Herrera, M. L. G., Hobson, K. A., Martínez, J. C., \& Méndez, C. G. (2006). Tracing the origin of dietary protein in tropical dry forest birds. Biotropica, $38,735-742$.

Herzog, S. K., Kessler, M., \& Cahill, T. M. (2002). Estimating species richness of tropical bird communities from rapid assessment data. Auk, 119, 749-769.

Hill, M. O. (1973). Diversity and evenness: A unifying notation and its consequences. Ecology, 54, 427-432.

Hiraldo, F., Delibes, M., \& Donazar, J. A. (1991). Comparison of diets of Turkey Vultures in three regions of Northern Mexico. Journal of Field Ornithology, $62,319-324$

Holm, S. (1979). A simple sequentially rejective multiple test procedure. Scandinavian Journal of Statistics, $6,65-70$.

Holmes, R. T., Bonney, R. E., \& Pacala, S. W. (1979). Guild structure of the Hubbard Brook bird community: A multivariate approach. Ecology, 60, 512-520.

Holmes, R. T., \& Recher, H. F. (1986). Determinants of guild structure in forest bird communities: An intercontinental comparison. Condor, 88, 427-439.

Howell, S. N. G., \& Dunn, J. (2007). Gulls of the Americas. New York, NY: Peterson Field Guides.

Hubbell, S. P. (2005). Neutral theory in community ecology and the hypothesis of functional equivalence. Functional Ecology, 19, 166-172.

ILWIS 3.3. (2005). ILWIS. Version 3.3. ITC, University of Twente. Enchende, Netherlands. http://www.itc. $\mathrm{nl} /$ ilwis

Jaksić, F. M. (1981). Abuse and misuse of the term "guild" in ecological studies. Oikos, 37, 397-400.

Jaksić, F. M., \& Medel, R. G. (1990). Objective recognition of guilds: testing for statistically significant species clusters. Oecologia, 82, 87-92.

Jiménez, J. (2004). Mangrove forests under dry seasonal climates in Costa Rica. In G. Frankie, A. Mata, \& S. Vinson (Eds), Biodiversity conservation in
Costa Rica: Learning the lesson in a seasonal dry forest (pp. 136-143). Berkley, USA: University of California Press.

Johnson, M. D., \& Sherry, T. W. (2001). Effects of food availability on the distribution of migratory warblers among habitats in Jamaica. Journal of Animal Ecology, $70,546-560$.

Kissling, W. D., Sekercioglu, C. H., \& Jetz, W. (2011). Bird dietary guild richness across latitudes, environments and biogeographic regions. Global Ecology and Biogeography, 21, 328-340.

Kolasa, J. (1989). Ecological systems in hierarchical perspective: Breaks in community structure and other consequences. Ecology, 70, 36-47.

Kolasa, J., \& Pickett, S. T. A. (1989). Ecological systems and the concept of biological organization. Proceedings of the National Academy of Sciences, $86,8837-8841$.

Korňan, M., \& Adamík, P. (2007). Foraging guild structure within a primaeval mixed forest bird assemblage: a comparison of two concepts. Community Ecology, $8,133-149$

Korňan, M., \& Kropil, R. (2014). What are ecological guilds? Dilemma of guild concepts. Russian Journal of Ecology, 45, 445-447.

Lefebvre, G., \& Poulin, B. (1997). Bird communities in Panamanian black mangroves: Potential effects of physical and biotic factors. Journal of Tropical Ecology, 13, 97-113.

Legendre, P., \& Legendre, L. 1998. Numerical ecology. Amsterdam, Holland: Elsevier science.

Levin, L. A., Boesch, D. F., Covich, A., Dahm, C., Erséus, C., Ewel, K. C., ...Weslawski, J. M. (2001). The function of marine critical transition zones and the importance of sediment biodiversity. Ecosystems, $4,430-451$

Mac Nally, R. (1994). Habitat-specific guild structure of forest birds in South-Eastern Australia: a regional scale perspective. Journal of Animal Ecology, 63, 988-1001.

Miranda, L., \& Collazo, J. A. (1997). Food habits of 4 species of wading birds (Ardeidae) in a tropical mangrove swamp. Colonial Waterbirds, 20, 413-418.

Morrison, M. L. (1984). Influence of sample size and sampling design on analysis of avian foraging behavior. Condor, 86, 146-150.

Noon, B. R. (1981). Techniques for sampling avian habitats 1. General Technical Report RM-87. Rocky Mountain Forest and Range Experiment Station, Colorado: USDA Forest Service. 
Noske, R. A. (1996). Abundance, zonation and foraging ecology of birds in mangroves of Darwin Harbour, Northern Territory. Wildlife Research, 23, 443-474.

Paulson, D. R. (2005). Shorebirds of North America: The photographic guide. Princeton, New Jersey: Princeton University Press.

Pianka, E. R. (1980). Guild structure in desert lizards. Oikos, 35, 194-201.

Pianka, E. R. (2000). Evolutionary ecology. San Francisco, California: Addison Wesley Educational Publishers.

Pickett, S. T. A., Kolasa, J., \& Jones, C. G. (2007). Ecological understanding. London: Academic Press.

PRIMER-E Ltd. (2007). Primer 6. Version 6.1.10. PRIMERE Ltd, Plymouth, UK. http//:www.primer-e.com

R Core Team. (2013). $R$ : A language and environment for statistical computing. R Foundation for Statistical Computing. Vienna, Austria. URL http://www.Rproject.org/

Ralph, C. J., Droege, S., \& Sauer, J. R. (1995). Managing and monitoring birds using point counts: standards and applications. In C. J. Ralph, J. R. Sauer, \& S. Droege (Eds.), Monitoring bird populations by point counts (pp. 161-168). Pacific Southwest Research Station, California: USDA Forest Service.

Ralph, C. J., Geupel, G. R., Pyle, P., Martin, T. E., DeSante, D. F., \& Mila, B. (1992). Manual de métodos de campo de aves terrestres. General Technical Report. Pacific Southwest Station, California: USDA Forest Service.

Rappole, J. H., Morton, E. S., Lovejoy, T. E., \& Ruos, J. L. (1983). Nearctic avian migrants in the Neotropics. Washington D.C.: USFWS-World Wildlife Fund U.S.

Remsen, Jr., J. V., Stiles, F. G., \& Scott, P. E. (1986). Frequency of arthropods in stomachs of tropical hummingbirds. Auk, 103, 436-441.

Rioja-Paradela, T., Carrillo-Reyes, A., \& Espinoza-Medinilla, E. (2014). Effect of temporal lakes on avifaunal composition at the Southeast of Isthmus of Tehuantepec, Oaxaca, Mexico. International Journal of Tropical Biology and Conservation, 62, 1523-1533.

Rodríguez, A., Jansson, G., \& Andrén, H. (2007). Composition of an avian guild in spatially structured habitats supports a competition-colonization trade-off. Proceedings of the Royal Society: B, 274, 1403-1411.

Root, R. B. (1967). The niche-expoitation pattern of the Blue-gray Gnatcatcher. Ecological Monographs, $37,317-350$
Ruiz Bruce Taylor, M. D. M., \& Bojorges Baños, J. C. (2014). Estimating species richness and density of a bird community in a coastal lagoon on the Mexican Pacific. Huitzil, 15, 64-81.

Ruiz Bruce Taylor, M. D. M., Rangel-Salazar, J. L., \& Cortés Hernández, B. (2013). Resilience in a Mexican Pacific mangrove after hurricanes: implications for conservation restoration. Journal of Environmental Protection, 4, 1383-1391.

Salthe, S. N. (2002). Summary of the principles of hierarchy theory. General Systems Bulletin, 31, 13-17.

Salthe, S. N. (2006). Two frameworks for complexity generation in biological systems. In C. Gershenson, \& T. Lenaerts (Eds.), Evolution of complexity, ALife $X W$ proceedings (pp. 99-104). Bloomington, Indiana: Indiana University Press.

Salthe, S. N. (2012). Hierarchical structures. Axiomathes, 22, 355-383.

Silva, J. M. C. S., \& Tenreyro, S. (2006). The log of gravity. Review of Economics and Statistics, 88, 641-658.

Simberloff, D., \& Dayan, T. (1991). The guild concept and the structure of ecological communities. Annual Review of Ecology and Systematics, 22, 115-143.

Simon, H. A. (1962). The architecture of complexity. Proceedings of the American Philosophical Society, 106, 467-482.

Snedaker, S. C., \& Lahmann, E. J. (1988). Mangrove understorey absence: a consequence of evolution? Journal of Tropical Ecology, 4, 311-314.

Sodhi, N. S., Choo, J. P. S., Lee, B. P. Y. H., Quek, K. C., \& Kara, A. U. (1997). Ecology of a mangrove forest bird community in Singapore. Raffles Bulletin of Zoology, 45, 1-13.

Stiles, F. G. (1980). Evolutionary implications of habitat relations between permanent and winter resident landbirds in Costa Rica. In A. Keast \& E. S. Morton (Eds.), Migrant birds in the Neotropics: Ecology, behavior, distribution and conservation (pp. 421435). Washington DC: Smithsonian Institution Press.

Stoner, A. W., \& Acevedo, C. (1990). The macroinfaunal community of a tropical estuarine lagoon. Estuaries, $13,174-181$.

Strong, A. M., Bancroft, G. T., \& Jewell, S. D. (1997). Hydrological constraints on Tricolored Heron and Snowy Egret resource use. Condor, 99, 894-905. 
Sugihara, G., Bersier, L. F., Southwood, T. R. E., Pimm, S. L., \& May, R. M. (2003). Predicting correspondence between species abundances and dendrograms of niche similarities. Proceedings of the National Academy of Sciences of the United States, 100, 5246-5251.

Trejo, I. (2004). Clima. In A. J. Garcia-Mendoza, M. J. de Jesús Ordóñez, \& M. Briones-Salas (Eds.), Biodiversidad de Oaxaca (pp. 67-85). Mexico City: Instituto de Biología UNAM/Fondo Oaxaqueño para la conservación de la naturaleza/World Wildlife Fund.

Waltho, N. \& Kolasa, J. (1994). Organization of instabilities in multispecies systems, a test of hierarchy theory. Proceedings of the National Academy of Sciences, 91, 1682-1685.
Wiens, J. A. (1989). The ecology of bird communities: Foundations and patterns. Cambridge, UK: Cambridge University Press.

Williams, P., Gibbons, D., Margules, C., Rebelo, A., Humphries, C., \& Pressey, R. (1996). A comparison of richness hotspots, rarity hotspots, and complementary areas for conserving diversity of british birds. Conservation Biology, 10, 155-174.

Williams, R. J., \& Martinez, N. D. (2004). Limits to trophic levels and omnivory in complex food webs: theory and data. American Naturalist, 163, 458-468.

Wilson, J. B. (1999). Guilds, functional types and ecological groups. Oikos, 86, 507-522.

See Digital Appendix at: / Ver Apéndice digital en:

revistas.ucr.ac.cr 